\title{
Development of Formaldehyde Adsorption using Modified Activated Carbon - A Review
}

\author{
W.D.P Rengga*, M. Sudibandriyo and M. Nasikin \\ Department of Chemical Engineering, Faculty of Engineering, Universitas Indonesia, \\ Kampus Universitas Indonesia, Depok 16424, INDONESIA
}

\section{Article history:}

Received July 05, 2012 Received in revised form August 11, 2012 Accepted August 15, 2012 Available online

\begin{abstract}
Gas storage is a technology developed with an adsorptive storage method, in which gases are stored as adsorbed components on the certain adsorbent. Formaldehyde is one of the major indoor gaseous pollutants. Depending on its concentration, formaldehyde may cause minor disorder symptoms to a serious injury. Some of the successful applications of technology for the removal of formaldehyde have been reported. However, this paper presents an overview of several studies on the elimination of formaldehyde that has been done by adsorption method because of its simplicity. The adsorption method does not require high energy and the adsorbent used can be obtained from inexpensive materials. Most researchers used activated carbon as an adsorbent for removal of formaldehyde because of its high adsorption capacity. Activated carbons can be produced from many materials such as coals, woods, or agricultural waste. Some of them were prepared by specific activation methods to improve the surface area. Some researchers also used modified activated carbon by adding specific additive to improve its performance in attracting formaldehyde molecules. Proposed modification methods on activation and additive impregnated carbon are thus discussed in this paper for future development and improvement of formaldehyde adsorption on activated carbon. Specifically, a waste agricultural product is chosen for activated carbon raw material because it is renewable and gives an added value to the materials. The study indicates that the performance of the adsorption of formaldehyde might be improved by using modified activated carbon. Bamboo seems to be the most appropriate raw materials to produce activated carbon combined with applying chemical activation method and addition of metal oxidative catalysts such as $\mathrm{Cu}$ or Ag in nano size particles. Bamboo activated carbon can be developed in addition to the capture of formaldehyde as well as the storage of adsorptive hydrogen gas that supports renewable energy.
\end{abstract}

Keywords: adsorption; bamboo; formaldehyde; modified activated carbon; nano size particles

\section{Introduction}

Gas storage technology is the method of "adsorptive storage", where the gases are stored in the adsorbed state on the certain "adsorbent". Gas molecules have a density in the adsorbed state which is close to the density of the melting state. Hydrogen storage describes a method for storing hydrogen for later use. Hydrogen storage is used to provide renewable energy sources as a provider of fuel for transportation. Storage by melting method is superior, but this requires a very high cost in terms of equipment and energy required. The method of storing hydrogen is performed in a gas cylinder tube which was filled with an activated carbon. Gas pressure can be flexibly adapted to the gas source. Subsequent adsorption technology is used for the adsorption of formaldehyde which is a toxic gas.

Gaseous formaldehyde is one of the major indoor gaseous pollutants. This volatile organic compound is derived from the paint, decoration materials, polymerizing plate, binder of furniture, fiber carpet [1, 2]. Formaldehyde is a reagent for adhesives such as urea formaldehyde and phenol-formaldehyde. Formaldehyde at low concentration can cause

\footnotetext{
* Corresponding author: Tel.: +62217863516, fax. +62217863515

Email: pita.rengga@gmail.com
} 
indisposition of throats at a level of about $0.1 \mathrm{mg} / \mathrm{m}^{3}$ $(0.08 \mathrm{ppm})$, irritation of eyes and noses at about 1 $\mathrm{mg} / \mathrm{m}^{3}$, difficult breathing at about $10 \mathrm{mg} / \mathrm{m}^{3}$, injury of respiratory organs at about $40 \mathrm{mg} / \mathrm{m}^{3}$, and asphyxia above $80 \mathrm{mg} / \mathrm{m}^{3}$ [3]. Even, formaldehyde can also result in lung cancer and eventually death.

Concentration limit allowable that formaldehyde exposed in the air by OSHA Permissible Exposure Limit (PEL) is up to $2 \mathrm{ppm} \mathrm{[4].} \mathrm{The} \mathrm{above} \mathrm{limitation} \mathrm{is} \mathrm{also}$ supported by the Indonesian government rules. In addition, World Health Organization recommended that the guideline for indoor air quality is $0,1 \mathrm{mg} / \mathrm{m} 3$ for 30 minutes to formaldehyde [5].

Efforts to reduce the content of formaldehyde indoor must be done, given the dangers posed and minimum allowable concentration limits. Several methods have been made to reduce formaldehyde gas phase at room and will be reviewed in this paper.

\section{Methods of Removing Indoor Formaldehyde Gas}

Efforts to reduce pollutants indoor, especially formaldehyde have been studied including the method of photo-catalyst, plasma, enzymes, and adsorption. There are also combined methods, such as adsorption and catalytic oxidation and adsorption and photocatalyst. Photo-catalyst oxidation methods for removing formaldehyde gas were done by using nano-structured $\mathrm{TiO}_{2}, \mathrm{Ag}-\mathrm{TiO}_{2}$ and $\mathrm{Ce}-\mathrm{TiO}_{2}$ [6] while plasma method were using various discharge plasmas. Liang et al used $\mathrm{NaNO}_{2}$ ferro-electric packed bed dielectric barrier discharge plasma reactor applying high-frequency AC power supply [7]. There is also DC Corona discharge plasma that can remove low-concentration of formaldehyde in the air by introduction of $\mathrm{MnOx} / \mathrm{Al}_{2} \mathrm{O}_{3}$ catalyst placed at downstream of the plasma reactor $[\mathbf{8}$, 9]. Cycle storage-discharge plasma catalytic process was applied to low-concentration formaldehyde removal from air using a combination of HZSM-5, HZ with $\mathrm{Ag}$, and $\mathrm{Cu}$ [10].

Formaldehyde can also be oxidized by alcohol in the present of oxidase enzyme. Alcohol oxidase is isolated from Hansenula polymorpha C-105 mutant overproducing this enzyme in glucose medium. Sigawi et al used a such method for removal and control of airborne formaldehyde [11].

A combination of adsorption and catalytic oxidation method was developed to hybrid catalyst for long lifetime clean removal formaldehyde indoors. This kind of hybrid catalyst was applied by Miyawaki et al using MnOx (functioned as a catalyst) and polyacrylonitrilbased nano fiber Activated Carbon (functioned as an adsorbent) [12].

Wide application of photo-catalysis in indoor air purification is limited due to the low formaldehyde level as contaminant of indoor air that can be handled. Lu et al used the nano size $\mathrm{TiO}_{2}$ particles immobilized on the surface of activated carbon filter which result in four time better removal of formaldehyde than using $\mathrm{TiO}_{2}$ on a flat glass [13].

\section{Adsorption of Formaldehyde Gas on Activated Carbon}

Adsorptions of formaldehyde gas on activated carbon have been conducted by several researchers. The activated carbons used varied on their origins and the method of physical or chemical activations. Properties of the activated carbon produced and the performance results in adsorbing formaldehyde gas for several researchers are presented in Table 1. Rong et al. used Rayon-based Activated Carbon Fiber activated by air oxidation at $420^{\circ} \mathrm{C}$ and heat treatment at $1223 \mathrm{~K}$. An oxidation treatment with air, activated carbon shows $260 \mathrm{~mL} / \mathrm{g}$ formaldehyde adsorption capacity [14, 15]. On the heat treatment of activated carbon can adsorbs as much as $336 \mathrm{~mL}$ of formaldehyde gas per gram of activated carbon for a continuous intake of $80 \mathrm{ppm}$ of formaldehyde in air. Boonamnuayvitaya et al used activated carbon from coffee residue, impregnated with $\mathrm{ZnCl}_{2}$ and activated in a stream of nitrogen. Based on the isotherm adsorption obtained in their study, maximum formaldehyde adsorbed was $360 \mathrm{~mL} / \mathrm{g}$ at equilibrium gas concentration of 74216 ppm. Kumagai et al used activated carbon from heat-treated rice husks in the flow of $\mathrm{CO}_{2}$ [16]. Only $0.1 \mathrm{mg} / \mathrm{g}$ was adsorbed at 1 ppm of formaldehyde. Pei and Zhang used chemically treated commercial activated carbon (it was not mentioned what kind of treatment they used). The results showed that $0.36 \mathrm{mg} / \mathrm{g}$ can be adsorbed at equilibrium concentration of formaldehyde of $2.36 \mathrm{ppm}$ [17]. Study on adsorption of gaseous formaldehyde on activated carbon derived from dewatered sewage sludge was conducted by Wen et al. The sewage sludge was carbonized in the flow of $\mathrm{N}_{2}$ at a temperature $450^{\circ} \mathrm{C}$ followed by impregnated with $\mathrm{ZnCl}_{2}$ and activated at $750^{\circ} \mathrm{C}$. The results showed that formaldehyde adsorption capacity could achieve $74.27 \mathrm{mg} / \mathrm{g}$ and 7.62 $\mathrm{mg} / \mathrm{g}$ [18].

\section{Adsorption of Formaldehyde Gas on Modified Activated Carbon}

Potential of activated carbon in adsorbing formaldehyde can be increased by adding additives. The additive might be either a material that can generate functional groups to catch formaldehyde molecule on the surface of activated carbon or an oxidative catalyst metal that are also able to increase the attractive force of the activated carbon surface. Results of some studies on characteristics and Formaldehyde Gas adsorption Capacity on modified Activated Carbon are summarized on Table 2. 
Table 1

Properties of the activated carbon produced and the performance results in adsorbing formaldehyde gas in some studies

\begin{tabular}{|c|c|c|c|c|c|c|}
\hline \multirow{2}{*}{$\begin{array}{c}\text { Raw materials } \\
\text { for activated } \\
\text { carbon }\end{array}$} & \multirow[b]{2}{*}{ Activation } & \multirow{2}{*}{$\begin{array}{l}\text { Surface area } \\
\quad\left(\mathrm{m}^{2} / \mathrm{g}\right)\end{array}$} & \multirow{2}{*}{ Process } & \multicolumn{2}{|c|}{ Formaldehyde gas } & \multirow{2}{*}{ Researcher } \\
\hline & & & & Inlet & $\begin{array}{l}\text { Amount } \\
\text { adsorbed }\end{array}$ & \\
\hline \multirow[t]{4}{*}{$\begin{array}{l}\text { Rayon-based } \\
\text { activated carbon } \\
\text { fiber }\end{array}$} & $\begin{array}{l}\text { Air oxidation at } 420^{\circ} \mathrm{C} \text { for } 1 \mathrm{~h} \text {, } \\
\text { then treated at } 950^{\circ} \text { for } 0.5 \mathrm{~h} \text {. } \\
\text { under } \mathrm{N}_{2} \text { flow }\end{array}$ & 1635 & batch & - & $\begin{array}{c}583.4 \\
(\mathrm{~mL} / \mathrm{g})\end{array}$ & [14] \\
\hline & & & $\begin{array}{l}\text { Continuous. } \\
\text { Flowrate }=500 \mathrm{~mL} / \mathrm{min} \text {. }\end{array}$ & - & $\begin{array}{c}260 \\
(\mathrm{~mL} / \mathrm{g})\end{array}$ & \\
\hline & $\begin{array}{l}\text { At } 850^{\circ} \mathrm{C} \text { in steam under } \mathrm{N}_{2} \\
\text { flow, then heat-treatment at } \\
950^{\circ} \mathrm{C} \text { for } 0,5 \mathrm{~h} \text { under } \mathrm{N}_{2} \text { flow }\end{array}$ & 2121 & Batch & - & $\begin{array}{l}723.6 \\
(\mathrm{~mL} / \mathrm{g})\end{array}$ & [15] \\
\hline & & & $\begin{array}{l}\text { Continuous. } \\
\text { Flowrate }=500 \mathrm{~mL} / \mathrm{min} .\end{array}$ & $\begin{array}{c}80 \\
(\mathrm{~mL} / \mathrm{g})\end{array}$ & $\begin{array}{c}336 \\
(\mathrm{~mL} / \mathrm{g})\end{array}$ & \\
\hline Coffee residue & $\begin{array}{l}\mathrm{ZnCl}_{2} \text { (3 part) ; Pyrolisis under } \\
\mathrm{N}_{2} \text { flow for } 1 \mathrm{~h} \text {. }\end{array}$ & $470 \pm 12$ & batch & $\begin{array}{l}13767, \\
30431, \\
50899, \\
74216 \\
(p p m)\end{array}$ & $\begin{array}{c}260 \\
285 \\
320 \\
360 \\
(\mathrm{~mL} / \mathrm{g})\end{array}$ & [1] \\
\hline Rice husk & $\begin{array}{l}\text { At } 875^{\circ} \mathrm{C} \text { in } \mathrm{N}_{2} \text { flow for } 1 \mathrm{~h} \text {., then } \\
\text { at } 875^{\circ} \mathrm{C} \text { in a } \mathrm{CO}_{2} \text { flow. }\end{array}$ & 466.9 & batch & $\begin{array}{c}1.0 \\
(\mathrm{ppm})\end{array}$ & $\begin{array}{c}0.1 \\
(\mathrm{ppm})\end{array}$ & [16] \\
\hline $\begin{array}{l}\text { Chemically } \\
\text { treated activated } \\
\text { carbon }\end{array}$ & Unkown treatment & 970 & Continuous & $\begin{array}{l}2.36 \pm 0,1 \\
(\mathrm{ppm})\end{array}$ & $\begin{array}{l}33.565 \\
(\mathrm{mg} / \mathrm{g})\end{array}$ & [17] \\
\hline Sewage sludge & $\begin{array}{l}\text { Carbonized at } 450^{\circ} \mathrm{C} \text { for } 1.5 \mathrm{~h} \text {. } \\
\text { under } \mathrm{N}_{2} \text { flow, then activated } \\
\text { with } \mathrm{ZnCl}_{2} \text { ( } 1 \text { part) at } 750^{\circ} \mathrm{C} \text { for } \\
120 \mathrm{~min} \text {. }\end{array}$ & 509.88 & Batch & $\begin{array}{c}498 \\
0.41 \\
\left(\mathrm{mg} / \mathrm{m}^{3}\right)\end{array}$ & $\begin{array}{c}74.27 \\
7.62 \\
(\mathrm{mg} / \mathrm{g})\end{array}$ & [18] \\
\hline
\end{tabular}

Table 2

Characteristics and Adsorptive Capacity of Formaldehyde Gas on to Activated Carbon

\begin{tabular}{|c|c|c|c|c|c|c|}
\hline \multirow{2}{*}{$\begin{array}{c}\text { Raw } \\
\text { materials for } \\
\text { activated } \\
\text { carbon }\end{array}$} & \multirow[b]{2}{*}{ Modification } & \multirow{2}{*}{$\begin{array}{l}\text { Surface } \\
\text { area, } \\
\mathrm{m}^{2} / \mathrm{g}\end{array}$} & \multirow[b]{2}{*}{ Process } & \multicolumn{2}{|c|}{ Formadehyde gas } & \multirow{2}{*}{ Researcher } \\
\hline & & & & Inlet & $\begin{array}{l}\text { Amount } \\
\text { adsorbed }\end{array}$ & \\
\hline Nutshell & $\begin{array}{l}\text { Diaminated with } \mathrm{HNO}_{3} \text { and } \\
\mathrm{H}_{2} \mathrm{SO}_{4} \text { for } 24 \mathrm{~h} \text {, then reduced } \\
\text { by Fe powder and } \mathrm{HCl} \text { for } 60 \\
\text { min }\end{array}$ & 950 & batch & - & $2(\mathrm{mg} / \mathrm{g})$ & [19] \\
\hline $\begin{array}{l}\text { Activated } \\
\text { carbon articles } \\
(<300 \mu \mathrm{m})\end{array}$ & $\begin{array}{l}\text { Mixed with } \mathrm{MnO}_{2} \\
(<10 \mu \mathrm{m}) 77 \% \mathrm{~b} \text {. } \\
\text { Blended with a resin binder } \\
\text { to make Board-like air } \\
\text { cleaning material }\end{array}$ & & $\begin{array}{l}\text { Continuous. } \\
\text { Flowrate } \\
500-1000 \\
\mathrm{~mL} / \mathrm{min}\end{array}$ & $0.25(\mathrm{ppm})$ & $\begin{array}{l}0.04-0.05 \\
(\mathrm{ppm})\end{array}$ & [20] \\
\hline Grafite powder & $\begin{array}{l}\text { Modified by } \\
\text { 3-aminopropyl- } \\
\text { methyldiethoxysilane at } 105^{\circ} \mathrm{C}\end{array}$ & & batch & $\begin{array}{c}2.14 \\
(\mathrm{ppm})\end{array}$ & $\begin{array}{c}\text { 76.0, for } 4 \text { days } \\
36.1 \text {, for } 6 \text { days } \\
91.2 \text {, for } 8 \text { days } \\
66.5 \text {, for } 13 \text { days } \\
\text { (mg/g) ; } \\
0.96(\mathrm{ppm})\end{array}$ & [2] \\
\hline $\begin{array}{l}\text { Coal-based } \\
\text { Granular } \\
\text { activated } \\
\text { carbon } \\
\text { (commercial) }\end{array}$ & $\begin{array}{l}\text { impregnated with Ag nano } \\
\text { particles }\end{array}$ & $641 \pm 12$ & $\begin{array}{l}\text { Continuous, } \\
\text { Flowrate= } \\
378 \mathrm{~mL} / \mathrm{min}\end{array}$ & $\begin{array}{c}1000 \\
\mathrm{mg} / \mathrm{m}^{3} \\
9 \pm 1(\mathrm{ppm})\end{array}$ & $1.56(\mathrm{mg} / \mathrm{g})$ & [21] \\
\hline
\end{tabular}


Tanada et al used activated carbon from nutshell, diaminated with $\mathrm{HNO}_{3}$ and $\mathrm{H}_{2} \mathrm{SO}_{4}$, and impregnated with Fe [19]. The capacity of activated carbon obtained on adsorbing formaldehyde gas reached $2 \mathrm{mg} / \mathrm{g}$. Sekine and Nishimura developed a board-like air-cleaning material consisting of activated carbon particles and manganese oxides to remove formaldehyde gas from the air. However, the results were not very good where only $0.05 \mathrm{mg} / \mathrm{g}$ can be adsorbed in this material [20]. Matsuo et al used graphite powder prepared with 3aminopropyl-methyldiethoxysilane at $105 \mathrm{oC}$ to adsorb formaldehyde. Only little formaldehyde (0.96 ppm) can be adsorbed in their experiments [2]. Much better results were obtained by Shin and Song where they used silver nano-particles attached onto the surface of granulated activated carbon (coal based) using the sputtering method. The mass of formaldehyde removed by this combination of adsorption and catalytic oxidation was 2.4 times higher than that by the bare activated carbon at a gas retention time of 0.5 second. The amount adsorbed reached as much as $1.56 \mathrm{mg} / \mathrm{g}$ [21].

Table 3

Research Results on Developing Activated Carbon Using Various Agricultural By-Product Materials And Activation Methods

\begin{tabular}{|c|c|c|c|c|c|c|}
\hline $\begin{array}{l}\text { Originally } \\
\text { activated carbon }\end{array}$ & Carbonized & Activation & $\begin{array}{l}\text { Activator } \\
\text { /sample }\end{array}$ & $\begin{array}{c}\text { Surface } \\
\text { area, } \mathbf{m}^{2} / g\end{array}$ & $\begin{array}{c}\text { Total Pore } \\
\text { volume } \\
\mathrm{cm}^{3} / \mathrm{g}\end{array}$ & Researcher \\
\hline Bamboo & $\begin{array}{l}\text { carbonized at } \\
700^{\circ} \mathrm{C} \text { under } \mathrm{N}_{2} \\
\text { flow for } 1 \mathrm{~h}\end{array}$ & $\begin{array}{l}\text { Activated by } \mathrm{KOH} \text { at } 850 \\
{ }^{\circ} \mathrm{C} \text { for } 2 \mathrm{~h}\end{array}$ & $1: 1$ & 1896 & 1.109 & {$[22]$} \\
\hline Japanese Rice husks & $\begin{array}{l}\text { carbonized at } \\
875^{\circ} \mathrm{C} \text { in } \mathrm{N}_{2} \text { flow } \\
\text { for } 1 \mathrm{~h}\end{array}$ & $\begin{array}{l}\text { activated at } 875{ }^{\circ} \mathrm{C} \text { in } \mathrm{CO}_{2} \\
\text { flow for } 1 \mathrm{~h}\end{array}$ & - & 466.7 & 0.35 & [16] \\
\hline $\begin{array}{l}\text { Waste bamboo } \\
\text { scaffolding }\end{array}$ & - & $\begin{array}{l}\text { Activated by } \mathrm{H}_{3} \mathrm{PO}_{4} \text { firstly } \\
\text { at } 150^{\circ} \mathrm{C} \text { and then } \\
600^{\circ} \mathrm{C} \text { under flowing } \\
\text { nitrogen }\end{array}$ & - & $758-1869$ & $0.423-1.044$ & [23] \\
\hline Vertiver root & $\begin{array}{l}\text { Carbonized at } \\
800^{\circ} \mathrm{C} \text { for } 1 \mathrm{~h} \text {, } \\
\text { under flow } \mathrm{N}_{2} \text {. }\end{array}$ & $\begin{array}{l}\text { Activated in steam } \\
\text { under flow } \mathrm{N}_{2} \text { at } 80 \circ \mathrm{C} \text { for } \\
8 \mathrm{~h} \text { impregnation } \mathrm{H}_{3} \mathrm{PO}_{4} \\
\text { for } 24 \mathrm{~h}\end{array}$ & $1: 1$ & 1272 & 1.19 & [24] \\
\hline $\begin{array}{l}\text { Cotton stalk fiber } \\
\text { (China) }\end{array}$ & \multicolumn{2}{|c|}{$\begin{array}{l}\mathrm{KH}_{2} \mathrm{PO}_{4} 4 \%,\left(\mathrm{KH}_{2} \mathrm{PO}_{4}+\text { sample }\right) \text { slurry at } 105^{\circ} \mathrm{C} \text {, } \\
\text { stabilized at } 250^{\circ} \mathrm{C} \text { for } 30 \mathrm{~min} \text {, carbonized at } \\
600^{\circ} \mathrm{C} \text { for } 30 \mathrm{~min} \text {, activated at } 800^{\circ} \mathrm{C} \text { for } 20 \mathrm{~min} \\
\text { under } \mathrm{N}_{2} \text { flow }\end{array}$} & 1: 60 & 1287 & 0.667 & [25] \\
\hline \multirow[t]{3}{*}{$\begin{array}{l}\text { Bamboo scaffolding } \\
\text { (Hongkong) }\end{array}$} & \multirow{3}{*}{\multicolumn{2}{|c|}{$\begin{array}{l}\text { ( } \mathrm{HCl}+\text { sample) slurry at } 105^{\circ} \mathrm{C} \text { for overnight, } \\
\text { Activated at } 900^{\circ} \mathrm{C}, 2 \mathrm{~h} \text {, under flow } \mathrm{N}_{2} \\
\left(\mathrm{HNO}_{3}+\text { sample) slurry at } 105^{\circ} \mathrm{C} \text { for overnight, }\right. \\
\text { Activated at } 900^{\circ} \mathrm{C}, 2 \mathrm{~h} \text {, under } \mathrm{N}_{2} \text { flow } \\
\mathrm{H}_{2} \mathrm{SO}_{4} \text { slurry at } 105^{\circ} \mathrm{C} \text { for overnight, } \\
\text { Activated at } 900^{\circ} \mathrm{C}, 2 \mathrm{~h} \text { under } \mathrm{N}_{2} \text { flow }\end{array}$}} & $4: 1$ & & & [26] \\
\hline & & & $4: 1$ & 488 & 0.288 & \\
\hline & & & $1: 1$ & 553 & 0.284 & \\
\hline $\begin{array}{l}\text { Moso bamboo } \\
\text { (Phyllostachys } \\
\text { pubescens, Japan }\end{array}$ & \multicolumn{2}{|c|}{$\begin{array}{l}\mathrm{K}_{2} \mathrm{CO}_{3} \text { slurry at } 110^{\circ} \mathrm{C} \text { for } 24 \mathrm{~h} \text {, then } 800^{\circ} \mathrm{C} \text { for } 1 \\
\mathrm{~h} \text { under flow } \mathrm{N}_{2}\end{array}$} & $2: 1$ & 2175 & 1.10 & [27] \\
\hline $\begin{array}{l}\text { Coconut shell } \\
\text { (Indonesia) }\end{array}$ & \multicolumn{2}{|c|}{$\mathrm{KOH}$ at $700^{\circ} \mathrm{C}$ for $1 \mathrm{~h}$, under $\mathrm{N}_{2}$ flow. } & $4: 1$ & 1056 & - & [28] \\
\hline \multirow[t]{2}{*}{ Sewage sludge } & \multirow{2}{*}{\multicolumn{2}{|c|}{$\begin{array}{l}\mathrm{H}_{3} \mathrm{PO}_{4} \text { with } 800 \mathrm{~W} \text { under flow } \mathrm{N}_{2} \text { (microwave) } \\
\mathrm{ZnCl}_{2} \text { with } 800 \mathrm{~W} \text { under flow } \mathrm{N}_{2} \text { (microwave) }\end{array}$}} & $1: 2$ & 290.6 & 0.168 & [9] \\
\hline & & & $1: 15$ & 377.1 & 0.243 & \\
\hline $\begin{array}{l}\text { Bamboo waste } \\
\text { discarded }\end{array}$ & \multicolumn{2}{|c|}{$\begin{array}{l}\text { The dried bamboo } / \mathrm{KOH} \text { mixture at } 800^{\circ} \mathrm{C} \text { under } \\
\text { flow } \mathrm{N}_{2} \text { for } 3 \mathrm{~h}\end{array}$} & $1: 2$ & 1532 & 0.4911 & [29] \\
\hline Rice husk (India) & $\begin{array}{l}\text { Carbonized on } \\
450^{\circ} \mathrm{C} \text { for } 1 \mathrm{~h} \\
\text { under } \mathrm{N}_{2} \text { flow }\end{array}$ & $\mathrm{ZnCl}_{2}$, activated $450^{\circ} \mathrm{C}, 2 \mathrm{~h}$ & - & 180.50 & 0.027 & [30] \\
\hline $\begin{array}{l}\text { Argan (Argania } \\
\text { spinosa) seed shells }\end{array}$ & $\begin{array}{l}\text { carbonized under } \\
\mathrm{N}_{2} \text { flow at } 500^{\circ} \mathrm{C} \\
\text { for } 3 \mathrm{~h} \text {, }\end{array}$ & $\begin{array}{l}\mathrm{KOH} \text { slurry } 60^{\circ} \mathrm{C} \text { then } 110^{\circ} \mathrm{C} \\
\text { to dryness, pyrolized under } \\
\mathrm{N}_{2} \text { flow } 300^{\circ} \mathrm{C} \text { for } 2 \mathrm{~h} \text { and } \\
\text { then at } 800^{\circ} \mathrm{C} \text { for } 3 \mathrm{~h}\end{array}$ & $4: 1$ & 2132 & 2.18 & [31] \\
\hline
\end{tabular}




\section{Future Development}

Efforts on finding more efficient adsorption method for removing formaldehyde gas from air have been continuously conducted by many researchers. Focus of the efforts is to improve the surface area of activated carbon by selecting better raw materials and choosing better activation methods.

Recently, agricultural by-products are the most favorable materials used to make activated carbon, the reasons are that these raw materials are renewable and potentially less expensive to manufacture. Table 3 shows research results on developing activated carbon using various agricultural by-product materials and activation methods. It can be concluded based on the table that bamboo is the most favorable material considering that it can produce large number surface area $\left(550-2100 \mathrm{~m}^{2} / \mathrm{g}\right)$. In addition, chemical activation using $\mathrm{KOH}$ also shows better result in term of surface area.

Further improvement to increase the capacity of activated carbon in adsorbing formaldehyde gas can also be done by adding metal oxidative catalyst to increase the attractive force of the activated carbon surface. Among the metal oxidative catalysts, $\mathrm{Cu}$ probably is the best choice because it is cheap, no toxic and has highly attractive for formaldehyde molecules or hydrocarbon molecules, in general. Addition of Ag nano particles on the surface of activated carbon, as done Shin and Song, however, is also a good alternative. It will not only increase the attractiveness of the activated carbon surface but also increase the surface area of the carbon, therefore increasing the capacity of the gas formaldehyde adsorption. Even though $\mathrm{Ag}$ is less reactive oxidation catalyst than $\mathrm{Cu}$, but the size of a silver metal in nano size will create more adsorption sites that can improve the performance of activated carbon adsorption.

\section{Conclusion}

The efforts to improve the performance of the adsorption of formaldehyde can be done by using modified activated carbon. Bamboo seems to be the most appropriate raw materials to produce activated carbon combined with applying $\mathrm{KOH}$ chemical activation method. Furthermore, addition of metal oxidative catalysts such as $\mathrm{Cu}$ or $\mathrm{Ag}$ in nano size particles will enhance the capacity of activated carbon in adsorbing formaldehyde gas. Further development of an active carbon can be used to adsorb and store hydrogen gas for hydrogen renewable energy sources.

\section{References}

[1] Boonamnuayvitaya V, Sae-ung S, Tathapanichakoon W (2005) Preparation of Activated Carbon from Coffee residue for the Adsorption of Formaldehyde. Separation and Purification Technology Vol: 42: 159-168.
[2] Matsuo Y, Nishino Y, Fukutsuka T, Sugie Y (2008) Removal of Formaldehyde from Gas Phase by Silylated Graphite Oxide Containing Amino Group. Carbon Vol. 46: 1159-74.

[3] Shi QW, Jia DY, Geng SB (2005) Prime Criminal of Indoor Air Pollution-Formaldehyde. China Journal Contamination Control Air Condition Technology Vol. 2: 38-44.

[4] MSDS Material Data Safety Sheet (2000) Formaldehyde, Canada: Mallinckrote Baker, Inc

[5] WHO (2010) World Health Organization Guidelines for Indoor Air Quality: Selected Pollutants, World Health Organization Regional Office of Europe.

[6] Liang W, Li J, \& Jin Y (2012) Photo-catalytic Degradation of Gaseous Formaldehyde by $\mathrm{TiO}_{2} / \mathrm{UV}, \mathrm{Ag} / \mathrm{TiO}_{2} / \mathrm{UV}$ and $\mathrm{Ce} / \mathrm{TiO}_{2} / \mathrm{UV}$. Building and Environment, 51: 345-350.

[7] Liang W, Li J, Li J-X, Zhu T, \& Jin Y-Q (2010). Formaldehyde Removal from Gas Streams by Means of $\mathrm{NaNO}_{2}$ Dielectric Barrier Discharge Plasma. Journal of Hazardous Materials, 175: 1090-95.

[8] Fan X, Zhu T, Sun Y, \& Yan X (2011) The Roles of Various Plasma Species in The Plasma and Plasma-Catalytic Removal of lowconcentration Formaldehyde in Air. Journal of Hazardous Materials, 196: 380-385.

[9] Wang X, Liang X, Wang Y, Wang X, Liu M, Yin D, Xia S, Zhao J, \& Zhang Y (2011) Adsorption of Copper (II) onto Activated Carbons from Sewage Sludge by Microwave-induced Phosphoric Acid and Zinc Chloride Activation. Desalination, 278: 231-237.

[10] Zhao D-Z, Li X-S, Shi C, Fan H-Y, \& Zhu A-M (2011) LowConcentration Formaldehyde Removal from Air Using A Cycled Storage-discharge (CSD) Plasma Catalytic Process. Chemical Engineering Science, 66: 3922-29.

[11] Sigawi S, Smutok O, Demkiv O, Zakalska O, Gayda G, Nitzan Y, Nisnevitch M, \& Gonchar M (2011) Immobilized FormaldehydeMetabolizing Enzymes from Hansenula polymorpha for Removal and Control of Airborne Formaldehyde. Journal of Biotechnology, 153: 138-144.

[12] Miyawaki J, Lee G-H, Yeh J, Shiratori N, Shimohara T, Mochida I, \& Yoon S-H (2011) Development of Carbon-Supported Hybrid Catalyst for Clean Removal of Formaldehyde Indoors. Catalysis Today, 185: 278-283.

[13] Lu Y, Wang D, Ma C, \& Yang H (2010) The Effect of Activated Carbon Adsorption on The Photocatalytic Removal of Formaldehyde. Building and Environment, 45: 615-621.

[14] Rong H, Ryu Z, Zheng J, \& Zhang Y (2002) Effect of Air Oxidation of Rayon-based activated Carbon Fibers on Adsorption Behavior for Formaldehyde. Carbon, 40: 2291-300.

[15] Rong H, Ryu Z, Zheng J, \& Zhang Y (2003) Influence of Heat Treatment of Rayon-based activated Carbon Fibers on The Adsorption of Formaldehyde. Journal of Colloid and Interface, 261: 207-212.

[16] Kumagai S, Sasaki K, Shimizu Y, \& Takeda K (2008) Formaldehyde and Acetaldehyde Adsorption Properties of HeatTreated Rice Husk. Separation and Purification Technology, 61: 398-403.

[17] Pei J, \& Zhang JS (2011) On Performance and Mechanisms of Formaldehyde Removal by Chemi-sorbents. Chemical Engineering Journal, 167: 59-66.

[18] Wen Q, Li C, Cai Z, Zhang W, Gao H, Chen L, Zeng G, Shu X, \& Zhao Y (2011) Study on Activated Carbon Derived from Sewage Sludge for Adsorption of Gaseous Formaldehyde. Bioresource Technology, 102: 942-947.

[19] Tanada S, Kawasaki N, Nakamura T, Araki M, \& Isomura M (1999) Removal of Formaldehyde by Activated Carbons Containing Amino Groups. Journal of Colloid and Interface Science, 214: 106-108.

[20] Sekine Y, \& Nishimura A (2001) Removal Formaldehyde from Indoor Air by Passive Type Air-cleaning Materials. Atmospheric Environment, 35: 2001-7.

[21] Shin SK \& Song JH (2011) Modeling and Simulations of The Removal of Formaldehyde Using Silver Nano-particles Attached to Granular Activated Carbon. Journal of Hazardous Materials, 194: 385-392.

[22] Hameed BH, Din ATM, \& Ahmad AL (2007) Adsorption of methylene blue onto bamboo-based activated carbon: Kinetics 
and Equilibrium Studies. Journal of Hazardous Materials, 141: 819-825.

[23] Chan LS, Cheung WH, \& McKay G (2008) Adsorption of Acid Dyes by Bamboo Derived Activated Carbon. Desalination, 218: 304312.

[24] Altenor S, Carene B, Emmanuel E, Lambert J, Ehrhardt J-J, \& Gaspard S, (2009) Adsorption Studies of Methylene Blue and Phenol onto Vetiver Roots Activated Carbon Prepared by Chemical Activation. Journal of Hazardous Materials, 165: 102939.

[25] Li K, Zheng Z, Huang X, Zhao G, Feng, J, \& Zhang J (2009) Equilibrium, Kinetic,and Thermodynamic Studies on The Adsorption of 2- Nitroaniline onto Activated Carbon Prepared from Cotton Stalk Fibre. Journal of Hazardous Materials, 166: 213-220.

[26] Mui ELK., Cheung WH, Valix M, \& McKay G (2010) Activated carbons from bamboo scaffolding using acid activation. Separation and Purification Technology, 74: 213-218.
[27] Horikawa T, Kitakaze Y, Sekida T, Hayashi J, \& Katoh M (2010) Characteristics and humidity control capacity of activated carbon from bamboo. Bioresource Technology, 101: 3964-69.

[28] Sudibandriyo M (2011) Production of Super Activated Carbon from Coal and Coconut Shell using Chemical Activation. International Journal of Chemical Engineering Research, 3: 8188.

[29] Hirunpraditkoon S, Tunthong N, Ruangchai A, \& Nuithitikul K (2011) Adsorption Capacities of Activated Carbons Prepared from Bambu by $\mathrm{KOH}$ Activation. World Academy of Science. Engineering and Technology, 78: 711-715.

[30] Sharma YC (2011) Adsorption Characteristics of a Low-Cost Activated Carbon for the Reclamation of Colored Effluents Containing Malachite Green. Journal Chemical Engineering Data, 56: 478-484.

[31] Elmouwahidi A, Zapata-Benabithe Z, Carrasco-Marín F, \& Moreno-Castilla C, (2012) Activated Carbons from KOHActivation of Argan (Argania spinosa) Seed Shells as Supercapacitor Electrodes. Bioresource Technology, 111: 185190. 